\title{
Genotypic and Pathogenic Diversity of Colletotrichum sublineola Isolates from Sorghum (Sorghum bicolor) and Johnsongrass (S. halepense) in the Southeastern United States
}

K. V. Xavier, Department of Plant Pathology. University of Kentucky, Lexington 40546-0312; E. S. G. Mizubuti, Departamento de Fitopatologia, Universidade Federal de Viçosa, CEP 36570-900, Viçosa, MG Brazil; M. V. Queiroz, Departamento de Microbiologia, Laboratório de Genética Molecular de Fungos/BIOAGRO, Universidade Federal de Viçosa, Av. PH. Rolfs s/n, CEP 36570-900, Viçosa, MG Brazil; S. Chopra, Department of Plant Science, Pennsylvania State University, University Park 16802; and L. Vaillancourt, ${ }^{\dagger}$ Department of Plant Pathology, University of Kentucky

\begin{abstract}
Anthracnose caused by Colletotrichum sublineola is an important disease of cultivated sorghum (Sorghum bicolor) worldwide. Anthracnose is also common on the ubiquitous wild sorghum relative Johnsongrass ( $S$. halepense). Analysis of repetitive molecular fingerprinting markers revealed that isolates of $C$. sublineola from both hosts in the southeastern United States were genotypically diverse, with relatively few haplotypes found in more than one location. With few exceptions, isolates recovered from S. bicolor belonged to a population that was genetically distinct from the population recovered from $S$. halepense. Twenty-three isolates from cultivated sorghum were all pathogenic to at least one of 13 heritage inbred lines of S. bicolor. In all, 4 of 10 isolates from S. halepense were also pathogenic to one or more of the lines, while the rest caused no disease in greenhouse assays. The four pathogenic isolates from $S$. halepense

were less aggressive, on average, than isolates from S. bicolor, although the ranges overlapped. Pathogenicity tests involving 15 representative pathogenic isolates from $S$. bicolor and S. halepense on eight heritage inbred lines of $S$. bicolor identified 12 races. The combined results of this study demonstrated that $C$. sublineola comprises two separate hostassociated subpopulations in the field, even though some isolates from $S$. halepense were able to cause disease on S. bicolor under ideal greenhouse conditions. Nonetheless, the apparent existence of infrequent cross-infection events in the field, indicated by molecular fingerprinting, suggests that Johnsongrass has the potential to serve as a refuge and an incubator for genetic diversity in C. sublineola, which can complicate efforts to develop and deploy resistant sweet sorghum varieties in the region.
\end{abstract}

Anthracnose, caused by the fungus Colletotrichum sublineola Henn. ex Sacc. \& Trotter 1913, is among the most important diseases of sorghum (Sorghum bicolor (L.) Moench) worldwide (Ali and Warren 1987; Chala et al. 2010b; Frederiksen and Odvody 2000; Jamil and Nicholson 1987; Warren 1986). Anthracnose can reduce yields of grain sorghum by $50 \%$ or more under warm and humid conditions in a susceptible variety (Ali and Warren 1987; Harris et al. 1964; Tesso et al. 2012). C. sublineola can infect all parts of the plant, including the stalk, peduncle, panicle, grain, and leaves (Ferreira and Warren 1982; Tesso et al. 2012). The pathogen can be spread over long distances via infested seed (Cardwell et al. 1989; Zhang et al. 2017). The primary control strategy for anthracnose in grain sorghum is the use of resistant cultivars (Chala et al. 2010a). Resistance is controlled mostly by single dominant genes, some with multiple allelic forms (Boora et al. 1998; Coleman and Stokes 1954; Le Beau and Coleman 1950; Tenkouano et al. 1993).

Although resistance is key for the management of anthracnose in grain sorghum, it frequently fails, and genotypes that provide high levels of resistance in one location often succumb to the disease in

${ }^{\dagger}$ Corresponding author: L. Vaillancourt; E-mail: vaillan@uky.edu

Funding: This work was supported by a grant from United States Department of Agriculture-National Institute of Food and Agriculture (2011-6700930017) to S. Chopra (Principal Investigator) and L. Vaillancourt (CoPrincipal Investigator).

Current address of K. V. Xavier: University of Florida, Gulf Coast Research and Education Center, 14625 CR 672, Wimauma, 33598

*The $\boldsymbol{e}$-Xtra logo stands for "electronic extra" and indicates that three supplementary figures and six supplementary tables are published online.

Accepted for publication 4 May 2018.

(c) 2018 The American Phytopathological Society another. This is thought to be related to the high degree of variability in the population of $C$. sublineola affecting grain sorghum (Casela and Frederiksen 1993; Casela et al. 1995, 1998, 2000, Chala et al. 2011; Prom et al. 2012). Genetic diversity within the pathogen population has been characterized by the use of repetitive molecular fingerprinting markers, including random amplified polymorphic DNA (RAPD), restriction fragment length polymorphisms (RFLP), and amplified fragment length polymorphisms (Chala et al. 2011; Guthrie et al. 1992; Prom et al. 2012; Vaillancourt and Hanau 1992; Valèrio et al. 2005).

The ability of $C$. sublineola to infect a differential series of grain sorghum cultivars has been used to identify a large number of races in this species (Ali and Warren 1987; Boora et al. 1998; Chala et al. 2011; Rosewich et al. 1998; Valèrio et al. 2005). The interaction between sorghum and $C$. sublineola was suggested to follow a genefor-gene pattern (Casela et al. 1995).

Sweet sorghum has been grown in the southeastern United States for more than 150 years on a relatively limited scale, primarily for the production of table syrup (Winberry 1980). During the Second World War, production was increased in the region to provide a substitute for imported cane sugar. Anthracnose disease became a serious problem in these plantations (Hunter and Anderson 1997; LeBeau et al. 1951). Although cultivation of sweet sorghum in the Southeast decreased dramatically after the war, it has continued to be an important specialty crop in Kentucky, which is one of the top producers of sorghum syrup in the United States (Bitzer 1997, 2009). Recently, interest in sweet sorghum as a potential source of biofuel has increased in the United States and worldwide (Bitzer 1997, 2009; Cutz et al. 2013; Kim and Day 2011; Koçar and Civaş 2013; Pederson 2010; Sarath et al. 2008; Sipos et al. 2009; Wheals et al. 1999; Yu et al. 2014). Anthracnose is listed as one of the most important diseases of sweet sorghum in Kentucky (Bitzer 2009), and it is also common on the hybrids that are increasingly grown in the Southeast for feedstock (Hagan et al. 2014). If sweet sorghum production continues to expand in the region, anthracnose has the potential to become a significant limiting factor. 
C. sublineola is also a pathogen of the weed Johnsongrass (S. halepense (L.) Pers), which is related to S. bicolor (Paterson et al. 1995) and is ubiquitous across the Southeast. Johnsongrass is genetically diverse (Morrell et al. 2005). This host diversity could lead to the selection and maintenance of multiple $C$. sublineola races in the population; thus, Johnsongrass could serve as a refuge and an incubator for genetic variation in the pathogen.

There is currently no information about the population structure of $C$. sublineola in the southeastern United States. The goal of this work was to characterize genotypic and pathogenic diversity among C. sublineola isolates from S. bicolor and S. halepense in Kentucky and other southeastern states where sweet sorghum production is increasing, and to investigate the frequency of cross-infection among the two plant species. This information will help to improve management recommendations for anthracnose in sweet sorghum if it is more widely grown in the region in the future.

\section{Materials and Methods}

Fungal isolates. A collection of 384 fungal isolates was compiled for this study (Supplementary Table S1). Most of the isolates were recovered in 2011 to 2015 from sweet, forage, or grain sorghum (S. bicolor) as well as from Johnsongrass (S. halepense) in Kentucky, Georgia, Alabama, and Florida. A few grain sorghum isolates previously collected in the 1980s up through 2013 from Indiana, Texas, Brazil, Burkina Faso, Zambia, South Africa, and Sudan were also included in parts of the study. The identities of the isolates as C. sublineola were confirmed based on morphological characters, including production of acervuli with setae on the diseased tissue and typical falcate conidia in planta and in culture.

Isolates were recovered from the margins of anthracnose lesions on leaves or stalks. Tissue pieces were soaked in $70 \%$ ethanol for $30 \mathrm{~s}$, then $10 \%$ sodium hypochlorite (Clorox) for $2 \mathrm{~min}$, followed by three washes with sterile water. Disinfected tissue pieces were dried on sterile paper towels and placed on potato dextrose agar (PDA; Difco Laboratories, Detroit, MI, USA) containing ampicillin $(0.1 \mathrm{mg} / \mathrm{ml})$. Cultures were incubated at $23^{\circ} \mathrm{C}$ under continuous fluorescent light. Isolates were purified by single sporing with a sporecutter device (Muse et al. 2003) and preserved on silica gel at $-80^{\circ} \mathrm{C}$ (Tuite 1969). Fungal isolates were routinely cultured on PDA at $23^{\circ} \mathrm{C}$ under continuous fluorescent light.

Genomic DNA extraction. Fungal conidia were harvested by flooding a 14-day-old PDA culture with water and rubbing gently with a sterilized plastic minipestle. The conidia were washed three times with sterile water. A volume of $10 \mathrm{ml}$ of potato dextrose broth (Difco Laboratories) was added to a $60-\mathrm{mm}$ Petri plate and inoculated with a conidial suspension to achieve a final concentration of $5 \times 10^{4}$ conidia/ml. Plates were incubated at $23^{\circ} \mathrm{C}$ under continuous fluorescent light for 7 days, after which mycelial mats were collected, frozen, and lyophilized. Genomic DNA was extracted by using the protocol of Thon et al. (2000). Briefly, the lyophilized mycelium was crushed to a fine powder, then mixed with $1.2 \mathrm{ml}$ of DNA extraction buffer (100 mM Tris, $\mathrm{pH}$ 7.5; $0.7 \mathrm{M} \mathrm{NaCl} ; 10 \mathrm{mM}$ EDTA; and $10 \mathrm{~g}$ of cetyltrimethylammonium bromide per liter). The mixture was incubated at $65^{\circ} \mathrm{C}$ for $30 \mathrm{~min}$ and then an equal volume of chloroform was added to each sample. The samples were centrifuged at 3,000 $\times g$ for $15 \mathrm{~min}$, the upper phase was transferred to a 1.5-ml Eppendorf tube, and the DNA was precipitated with 0.8 volume of isopropanol. After centrifugation, the pellets were washed with $70 \%$ ethanol and resuspended in Tris-EDTA buffer.

RFLP fingerprints with transposon probes. Proteins containing predicted transposase domains were identified by using the Protein Family Database (Pfam) to screen the predicted proteome of C. sublineola isolate CgS11 (Buiate et al. 2017). A partial putative transposase sequence related to transposon elements belonging to the Tc1-Mariner superfamily was identified that was similar to JMSE01000036, a predicted transposase sequence from C. sublineola isolate CsTX430BB (Baroncelli et al. 2014) (Supplementary Fig. S1). The reverse complement of the $\mathrm{CgSl1}$ sequence was used to design the transposase primers CsTn1F and CsTn1R (Table 1). Polymerase chain reaction (PCR) was performed using as a template genomic DNA from CgSl1. PCR conditions consisted of $3 \mathrm{~min}$ of denaturation at $94^{\circ} \mathrm{C}$; followed by 35 cycles of denaturation for $30 \mathrm{~s}$ at $94^{\circ} \mathrm{C}, 60 \mathrm{~s}$ of annealing at $57^{\circ} \mathrm{C}$, and $40 \mathrm{~s}$ of extension at $72^{\circ} \mathrm{C}$; and a final extension of $10 \mathrm{~min}$ at $72^{\circ} \mathrm{C}$. The resulting amplicon was sequenced and submitted to GenBank as CsTn1 (accession number KY006076). The amplicon was labeled with ${ }^{32} \mathrm{P}$ to produce a probe for Southern hybridization. Genomic DNA $(1 \mu \mathrm{g})$ from each fungal isolate was digested with the restriction enzyme HindIII. The digested DNA samples were separated on a $0.7 \%$ agarose gel and transferred to a positively charged nylon membrane. The membrane was cross-linked with UV light, and the DNA was hybridized with the radioactively labeled probe.

RFLP fingerprints with telomere probes. Telomere probes were produced by using a published PCR protocol (IJdo et al. 1991). PCR was performed with primers (TTAGGG) $)_{5}$ and (CCCTAA $)_{5}$ in the absence of template. The $100-\mu \mathrm{l}$ reactions contained $50 \mathrm{mM} \mathrm{KCl}, 10 \mathrm{mM}$ Tris- $\mathrm{HCl}(\mathrm{pH} 8.3), 1.5 \mathrm{mM} \mathrm{MgCl} 2,0.001 \%$ gelatin, $200 \mu \mathrm{M}$ each dNTP, $0.1 \mu \mathrm{M}$ each primer, and $2 \mathrm{U}$ of Taq DNA polymerase. The PCR amplification protocol consisted of 10 cycles of $1 \mathrm{~min}$ at $94^{\circ} \mathrm{C}$, $30 \mathrm{~s}$ at $55^{\circ} \mathrm{C}$, and $1 \mathrm{~min}$ at $72^{\circ} \mathrm{C}$; followed by 30 cycles each consisting of $1 \mathrm{~min}$ at $94^{\circ} \mathrm{C}, 30 \mathrm{~s}$ at $60^{\circ} \mathrm{C}$, and $90 \mathrm{~s}$ at $72^{\circ} \mathrm{C}$; and a final step of $5 \mathrm{~min}$ at $72^{\circ} \mathrm{C}$. The resulting amplicons were gel purified and labeled with ${ }^{32} \mathrm{P}$. Conditions for the Southern blot were as described above.

RAPD. Genomic DNA of Colletotrichum isolates was amplified by using the RAPD-PCR method (Williams et al. 1990), with 10 different 10-base random primers (Browning et al. 1999; Vaillancourt and Hanau 1992) (Table 1). Reactions were carried out in a final volume of $25 \mu \mathrm{l}$ containing $10 \mathrm{ng}$ of genomic DNA, 10× PCR buffer, $50 \mathrm{mM} \mathrm{MgCl} 2,200 \mu \mathrm{M}$ dNTP, $5 \mu \mathrm{M}$ primer, and $1 \mathrm{U}$ of $\mathrm{Taq}$ DNA polymerase. The PCR cycling protocol consisted of 3 cycles of $1 \mathrm{~min}$ of denaturation at $94^{\circ} \mathrm{C}, 1 \mathrm{~min}$ of annealing at $35^{\circ} \mathrm{C}$, and 2 min for extension at $72^{\circ} \mathrm{C}$; followed by 34 cycles of $1 \mathrm{~min}$ of denaturation at $94^{\circ} \mathrm{C}, 20 \mathrm{~s}$ of annealing at $40^{\circ} \mathrm{C}$, and $2 \mathrm{~min}$ of extension at $72^{\circ} \mathrm{C}$; with a final extension of $72^{\circ} \mathrm{C}$ for $10 \mathrm{~min}$. Amplicons were resolved on $1.0 \%$ agarose gels, stained with ethidium bromide, and visualized under UV light.

Identification and characterization of haplotypes. Isolates with the same band patterns were visually identified as members of the

Table 1. Random amplified polymorphic DNA (RAPD) and transposase primers used in this study

\begin{tabular}{|c|c|c|c|}
\hline Primer & Type & Primer sequence & Reference \\
\hline OPA 1 & RAPD & 5'CAGGCCCTTC3' & Vaillancourt and Hanau 1992 \\
\hline OPA 2 & RAPD & 5'TGCCGAGCTG3' & Vaillancourt and Hanau 1992 \\
\hline OPA 3 & RAPD & 5'AGTCAGCCAC3' & Vaillancourt and Hanau 1992 \\
\hline UBC 356 & RAPD & 5'GCGGCCCTCT3' & Browning et al. 1999 \\
\hline UBC 384 & RAPD & 5'TGCGCCGCTA3' & Browning et al. 1999 \\
\hline UBC 391 & RAPD & 5'GCGAACCTCG3' & Browning et al. 1999 \\
\hline UBC 357 & RAPD & 5'AGGCCAAATG3' & Browning et al. 1999 \\
\hline UBC 345 & RAPD & 5'GCGTGACCCG3' & Browning et al. 1999 \\
\hline OPA 11 & RAPD & 5'CAATCGCCGT3' & This publication \\
\hline OPA 18 & RAPD & 5'AGGTGACCGT3' & This publication \\
\hline CsTn1F & Transposase & 5'AATCCAGGCTGATCTTGGGC3' & This publication \\
\hline CsTn1R & Transposase & 5'CCTGGCGAGCCTTCTGATAG3' & This publication \\
\hline
\end{tabular}


same RFLP or RAPD haplotypes (Supplementary Table S2). A matrix including 105 clone-corrected $C$. sublineola isolates, generated by allele presence or absence for all 10 primers (Supplementary Table S3), was subjected to principal component analysis (PCA) as an exploratory tool to describe groups of individuals with genetic similarities. Subsequently, the discriminant analysis of principal components (DAPC) was performed to identify more robust groups of genetically similar isolates. The Bayesian information criterion was evaluated to define the optimal number of clusters based on visual assessment of a scree plot, followed by execution of 10 runs of the "find.clusters" function. The adegenet package for R was used for these analyses (Jombart 2008). Evidence for random mating was tested in the whole dataset considering no structure according to host of origin, or groups defined by statistical methods (see above), and also in the populations from $S$. halepense and from sweet sorghum (S. bicolor) separately. The $\mathrm{r}_{\mathrm{D}}$ index, a standardized index of association that estimates linkage disequilibrium, was used to test for random mating using 1,000 bootstraps (Agapow and Burt 2001).

Pathogenicity assays. Thirty-one isolates representing the most common RFLP haplotypes from a range of hosts and locations were tested for pathogenicity on the sweet sorghum variety Sugar Drip in the greenhouse (Supplementary Table S4). Due to limited space availability, the isolates were tested in two groups in separate experiments. The first experiment was repeated three times and the second was repeated twice. One isolate of $C$. graminicola from maize (M30.001) was used as a negative control in all experiments: this C. graminicola isolate is nonpathogenic on healthy sorghum plants (Torres et al. 2014). An aggressive isolate of C. sublineola from sweet sorghum (SS63.001) was included as a positive control in all experiments.

In all, 19 C. sublineola isolates from the original group of 31 were tested on between 7 and 12 additional inbred varieties of $S$. bicolor, including Honey, Simon, Bailey, Chinese Amber, Dale, Dwarf Yellow Milo, Cowper, Orange, Planter, N100, Della, and Keller. Isolates were again tested in two groups in separate experiments, each repeated twice, and each also including the positive and negative controls. Sugar Drip seed were obtained from Dr. Todd Pfeiffer at the University of Kentucky (UK). Seed of the other varieties were obtained from Dr. Gary Pederson at the Plant Genetic Resources Conservation Unit in Griffin, GA. All seed stocks were increased in 2012 at the UK Agronomy Farm in Lexington.

The fungal isolates were cultured on PDA at $23^{\circ} \mathrm{C}$ under continuous fluorescent light for 2 weeks. Production of inoculum was done according to a modified method of Prom et al. (2009). Sterile water $(10 \mathrm{ml})$ was added to each plate and conidia were loosened with a minipestle. The conidia were washed three times with sterile water. Sugar Drip sorghum grains were prepared for inoculation by washing and soaking them in water for $48 \mathrm{~h}$, then autoclaving twice $\left(121^{\circ} \mathrm{C}\right.$ for $30 \mathrm{~min}$ ). A conidial suspension was used to inoculate $40 \mathrm{~g}$ of autoclaved grains in a Petri plate to achieve a final concentration of $5 \times$ $10^{6}$ conidia/g. The plates were incubated for 14 days at $23^{\circ} \mathrm{C}$ in the dark.

Pathogenicity experiments were performed in the greenhouse as described previously (Xavier et al. 2017). Four sorghum seeds were sown per 20.32-cm pot, in a 3:2 mixture of Pro-Mix BX (Premiere Horticulture, Ltd., Riviere du Loup, PQ, Canada) and sterile topsoil.
A

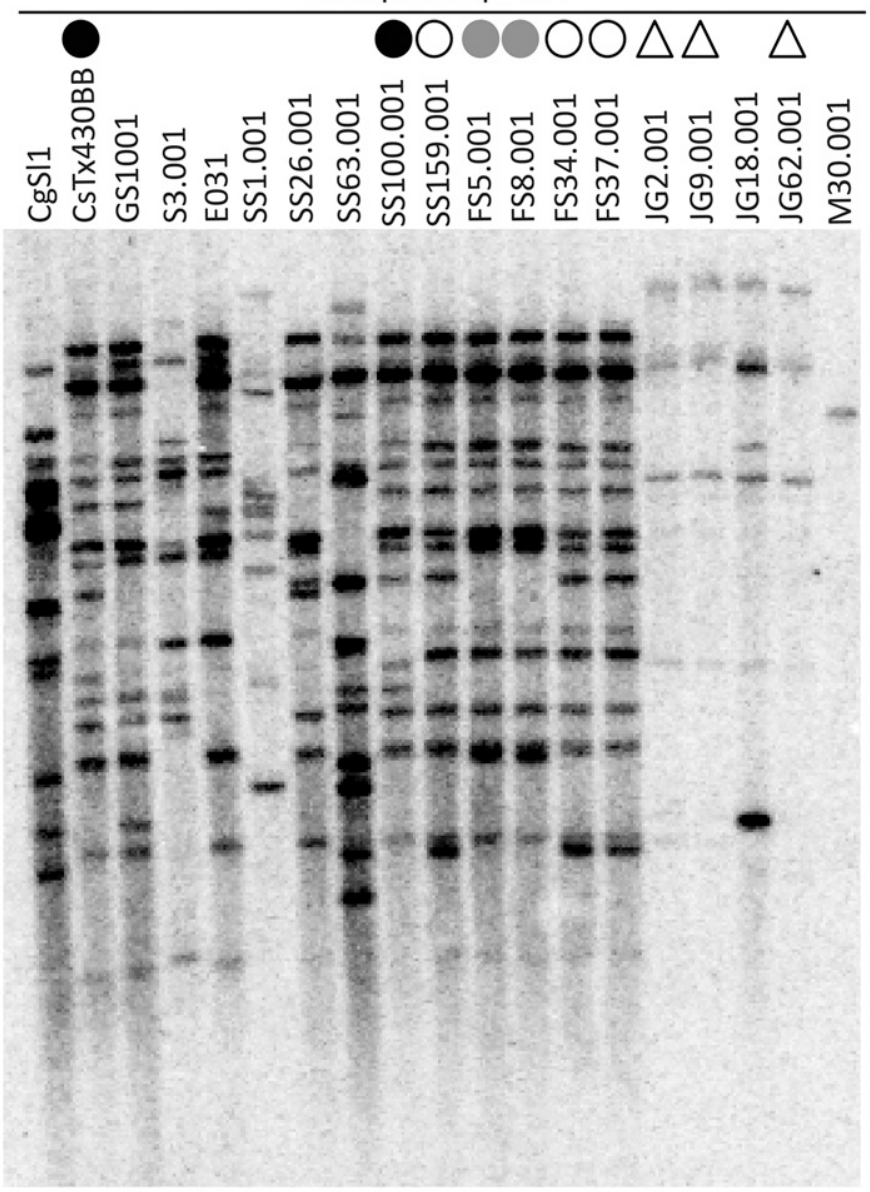

B

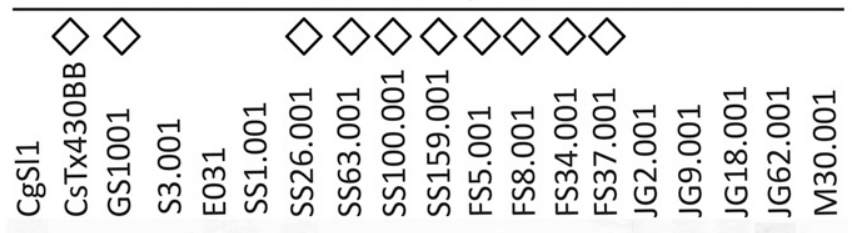

Fig. 1. Representative Southern blot analysis of Colletotrichum genomic DNA digested with Hindlll. The strain name is indicated above each lane. The same blot was hybridized with the $\mathbf{A}$, transposon and $\mathbf{B}$, telomere probes. Matching symbols above the lanes in A indicate strains with the same transposon haplotype. Diamond symbols above the lanes in $B$ indicate strains with similar patterns of hybridization with the telomere probe, classified as haplotype 33. Grain sorghum isolates of Colletotrichum sublineola were CgSl1, CsTX430BB, GS1.001, S3.001, and E031. Sweet sorghum isolates of C. sublineola are designated by the prefix "SS". Forage sorghum isolates are designated by the prefix "FS". Johnsongrass isolates are designated by the prefix "JG". M30.001 is an isolate of C. graminicola from maize. 
Pots were arranged in a randomized complete block design with four blocks. Each treatment replicate included two pots containing a total of eight plants. Plants were grown to the V5 or V6 stage, then inoculated by placing 10 colonized sorghum grains into the whorl of each plant.

Disease development was evaluated weekly, beginning 14 days after inoculation, for a period of 4 weeks. The disease evaluation was performed based on incidence, expressed as the number of infected plants (compatible interactions). Plants were scored as infected when sporulating acervuli were observed on the foliage.

Incidence values from the combined data sets from the repetitions of each experiment were used to calculate the area under the disease progress curve (AUDPC) by the trapezoidal integration method (Campbell and Madden 1990). The AUDPC data were subjected to analysis of variance after square root transformation before further analysis, to stabilize the variance. Treatment means were compared with the negative control (M30.001) by using the Dunnett's test procedure of the SAS software package (SAS Users Guide, version 9.4; SAS Institute, Cary, NC, USA). $P$ values $<0.05$ were considered significant.

\section{Results}

Molecular marker analysis. RFLP analyses, transposase probe. The CsTn1 transposase probe hybridized to multiple polymorphic restriction fragments in all of the Colletotrichum isolates. However, hybridization to the maize isolate and to a majority of the Johnsongrass isolates was relatively weak, with fewer fragments, compared with most isolates from $S$. bicolor. Representative results are shown in Figure 1A. In total, 61 different haplotypes could be identified with this probe (Table 2).

RFLP analyses, telomere probe. The telomere probe hybridized to one or more fragments in all of the Colletotrichum isolates and identified 49 different haplotypes (Table 2). The Johnsongrass isolates had diverse patterns of hybridization, consisting of between 1 and 36 individual bands (Fig. 1B). Among the grain sorghum isolates, the probe hybridized to between 1 and 24 fragments. None of the patterns with multiple hybridizing fragments matched those from the Johnsongrass isolates. Most of the isolates from forage and sweet sorghum had just one major band of the same or similar size when hybridized with the telomere probe (Fig. 1B). For this reason, telomere fingerprinting did not differentiate among the sweet and forage sorghum isolates. However, it could be used to distinguish between two groups: one with multiple bands, mostly from Johnsongrass and grain sorghum, and the other with a single major band, mostly from sweet and forage sorghum. The exceptions included seven grain sorghum isolates and one isolate from Johnsongrass that had the single major band, and seven isolates from sweet sorghum, representing three haplotypes, with multiple telomere bands.

Combined haplotypes. Among the 49 telomere haplotypes, only 2 included more than one transposon haplotype. One of these was type 33, which had only a single major hybridizing band and included the majority of sweet sorghum and forage sorghum isolates. The 273 isolates with telomere type 33 encompassed 35 transposon haplotypes. Among all 61 transposon haplotypes, 7 included more than one telomere haplotype but only three isolates had telomere haplotypes that were also found in combination with other transposon haplotypes. Thus, the transposon and telomere haplotypes were consistent for 381 of the 384 isolates (99\%). To maximize the available information, the isolates were classified into 85 groups based on the combined transposon-telomere haplotype (Table 2).

Only three combined haplotypes were found in more than one state. The most common of these was 17:33 (Fig. 2), which included 83 isolates from sweet sorghum and 15 from forage sorghum and was found in Kentucky and Alabama (Fig. 2). Haplotype 17:33 also included two isolates from grain sorghum: one from Texas and one from South Africa (Fig. 2). Two other haplotypes (19:33 and 21: 33) were found on both forage and sweet sorghum in Georgia, Florida, and Alabama. The remaining combined haplotypes were confined to a single host type and were found in only one location.

Among the Johnsongrass isolates, 34 different combined haplotypes could be discerned (Table 2). The Johnsongrass isolates displayed more diversity of combined haplotypes (haplotype richness) across most locations than the sweet sorghum isolates (Table 2). Nearly all of the haplotypes from Johnsongrass were found in only a single location (Fig. 2). However, there were four combined haplotypes that were more widely dispersed in Kentucky, including haplotypes 42:60 and 44:62, found in both Fayette and Franklin Counties (Fig. 2). None of these haplotypes was found outside Kentucky.

Analysis of genetic diversity among haplotypes. The telomere probe was not very informative for a large group of isolates from

Table 2. Combined haplotype richness by host and by location (locations with only one isolate were not included) ${ }^{\mathrm{a}}$

\begin{tabular}{|c|c|c|c|c|c|c|c|c|c|}
\hline Host & $N^{\mathbf{b}}$ & Trans $^{c}$ & Telo $^{d}$ & Comb $^{\mathbf{e}}$ & $\begin{array}{l}\text { Haplotype } \\
\text { richness }\end{array}$ & Location & $\begin{array}{l}\text { Number of } \\
\text { isolates }\end{array}$ & $\begin{array}{c}\text { Number of combined } \\
\text { haplotypes }\end{array}$ & $\begin{array}{l}\text { Haplotype } \\
\text { richness }\end{array}$ \\
\hline \multirow[t]{6}{*}{ Johnsongrass } & 87 & 14 & 33 & 34 & 0.39 & Fayette, KY & 18 & 6 & 0.33 \\
\hline & $\ldots$ & $\ldots$ & $\ldots$ & $\ldots$ & $\ldots$ & Franklin, KY & 13 & 6 & 0.46 \\
\hline & $\ldots$ & $\ldots$ & $\ldots$ & $\ldots$ & $\ldots$ & Russell, KY & 35 & 15 & 0.43 \\
\hline & $\ldots$ & $\ldots$ & $\ldots$ & $\ldots$ & $\ldots$ & Macon, AL & 7 & 1 & 0.14 \\
\hline & $\ldots$ & $\ldots$ & $\ldots$ & $\ldots$ & $\ldots$ & Tift, GA & 6 & 2 & 0.33 \\
\hline & $\ldots$ & $\ldots$ & $\ldots$ & $\ldots$ & $\ldots$ & Gadson, FL & 7 & 6 & 0.86 \\
\hline \multirow{5}{*}{$\begin{array}{l}\text { Sweet } \\
\text { sorghum }\end{array}$} & 229 & 32 & 5 & 35 & 0.15 & Brewton, AL & 24 & 1 & 0.04 \\
\hline & $\ldots$ & $\ldots$ & $\ldots$ & $\ldots$ & $\ldots$ & Macon, AL & 8 & 1 & 0.13 \\
\hline & $\ldots$ & $\ldots$ & $\ldots$ & $\ldots$ & $\ldots$ & Tift, GA & 67 & 17 & 0.25 \\
\hline & $\ldots$ & $\ldots$ & $\ldots$ & $\ldots$ & $\ldots$ & Live Oak, FL & 77 & 17 & 0.22 \\
\hline & $\ldots$ & $\ldots$ & $\ldots$ & $\ldots$ & $\ldots$ & $\begin{array}{l}\text { Montgomery, } \\
\text { KY }\end{array}$ & 51 & 1 & 0.02 \\
\hline \multirow{3}{*}{$\begin{array}{l}\text { Forage } \\
\text { sorghum }\end{array}$} & 49 & 3 & 1 & 3 & 0.06 & Brewton, AL & 29 & 3 & 0.10 \\
\hline & $\ldots$ & $\ldots$ & $\ldots$ & $\ldots$ & $\ldots$ & Cullman, AL & 8 & 2 & 0.25 \\
\hline & $\ldots$ & $\ldots$ & $\ldots$ & $\ldots$ & $\ldots$ & Macon, AL & 12 & 2 & 0.17 \\
\hline \multirow[t]{3}{*}{ Grain sorghum } & 18 & 15 & 12 & 16 & 0.88 & United States & 4 & 4 & 1 \\
\hline & $\ldots$ & $\ldots$ & $\ldots$ & $\ldots$ & $\ldots$ & Brazil & 9 & 8 & 0.89 \\
\hline & $\ldots$ & $\ldots$ & $\ldots$ & $\ldots$ & $\ldots$ & Africa & 5 & 5 & 1 \\
\hline
\end{tabular}

\footnotetext{
${ }^{\text {a }}$ Haplotype richness $=$ number of haplotypes divided by the number of strains

$\mathrm{b}$ Total number of isolates.

c Total transposase haplotypes.

$\mathrm{d}$ Total telomere haplotypes.

e Total combined haplotypes.
} 
S. bicolor that had only a single hybridizing fragment, while the transposon probe hybridized relatively poorly to the majority of isolates from $S$. halepense. Thus, we also characterized the isolates by amplifying them with RAPD primers. Isolates that shared the same patterns of bands for all 10 primers in multiple replicated experiments were considered to belong to the same RAPD haplotype. Representative results are shown in Supplementary Figure S2. RAPD analysis was performed for 358 of the isolates, identifying 281 haplotypes
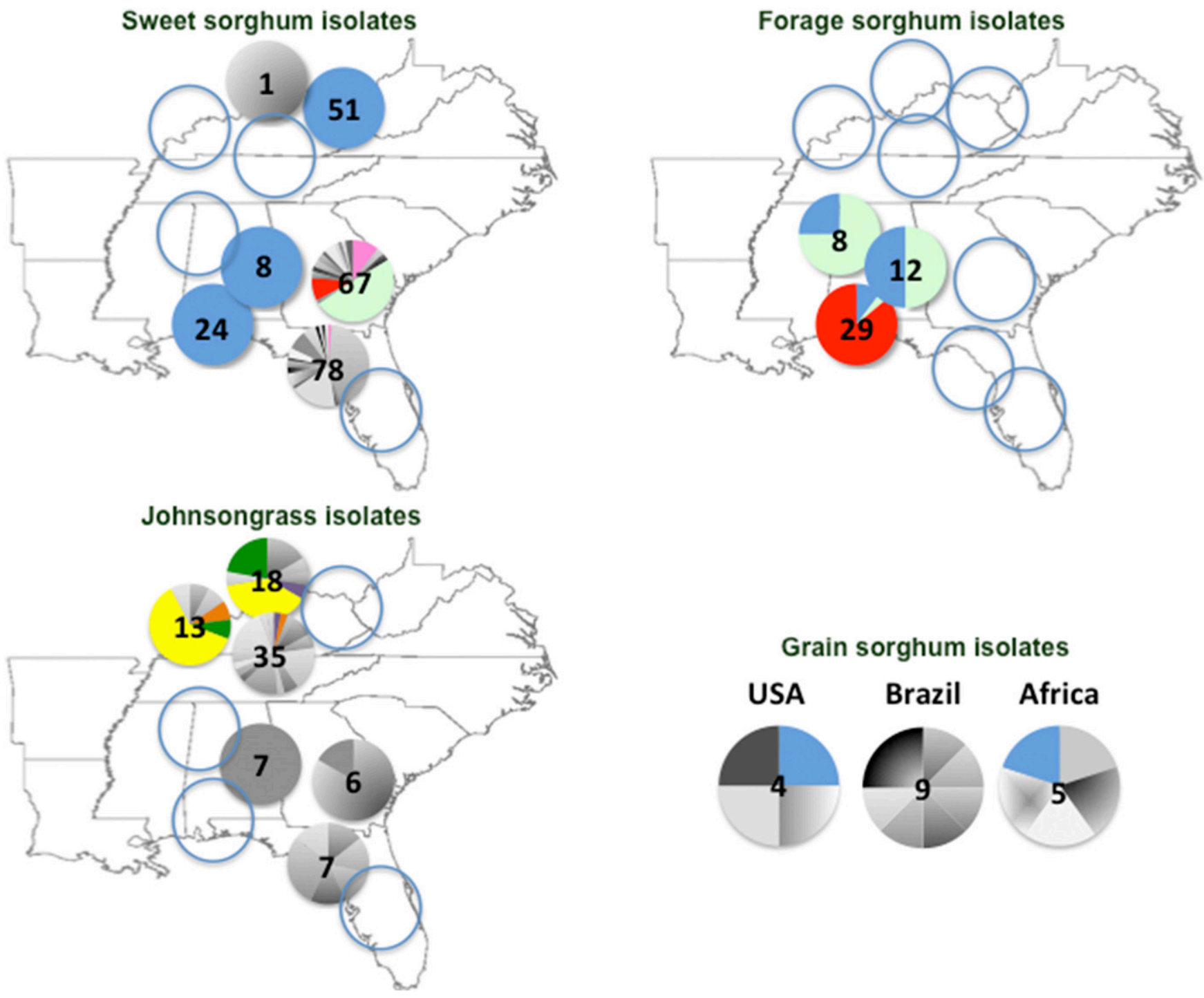

Fig. 2. Regional distribution of combined haplotypes. Pie slices that are the same colors represent the same combined haplotype found in different locations or on different host types. Slices in gray tones represent unique combined haplotypes that were found only in that location. The total number of isolates from each location is presented in the center of each pie graph. Empty circles represent locations from which no isolates of that category were obtained.

Table 3. Numbers of haplotypes identified among Colletotrichum isolates from Johnsongrass and from sweet, forage, and grain sorghum based on random amplified polymorphic DNA (RAPD) and on hybridization with the telomere or transposon probes

\begin{tabular}{lcclr}
\hline Plants & Number of strains & Number of locations & Probes & Individual haplotypes \\
\hline Johnsongrass & 85 & 7 & RAPD & 77 \\
& $\ldots$ & $\ldots$ & Telomere & 33 \\
Sweet sorghum & $\ldots$ & $\ldots$ & Transposon & 14 \\
& 214 & 6 & RAPD & Telomere \\
Forage sorghum & $\ldots$ & $\ldots$ & Transposon & 5 \\
& $\ldots$ & $\ldots$ & RAPD & 31 \\
Grain sorghum & 42 & 3 & Telomere & 173 \\
& $\ldots$ & $\ldots$ & Transposon & 3 \\
Total & $\ldots$ & $\ldots$ & RAPD & 11 \\
& 16 & 15 & Telomere & 11 \\
& $\ldots$ & $\ldots$ & Transposon & 16 \\
& $\ldots$ & $\ldots$ & RAPD & Telomere \\
\hline
\end{tabular}

${ }^{\text {a }}$ Total includes one maize strain of Colletotrichum graminicola. 
(Table 3). Most of the haplotypes were represented by only one isolate. Among the 37 RAPD haplotypes that included two or more isolates (comprising a total of 114 isolates), 29 consisted only isolates with the same combined RFLP (transposase and telomere) haplotype. The other eight RAPD haplotypes included isolates with more than one combined RFLP haplotype, suggesting the possibility of homoplasy for some of the RAPD markers. Nonetheless, the RAPD haplotypes were consistent with the combined RFLP haplotypes for more than $95 \%$ of all isolates.

Individual polymorphic bands for $105 C$. sublineola isolates with unique RAPD haplotypes, representing 76 combined RFLP haplotypes, were manually scored and entered into a matrix. Data were analyzed by PCA, initially without assuming any groupings by host or origin. The results provided evidence for a population structure that was strongly associated with host species (Fig. 3). Thus, the majority of isolates from S. bicolor (including isolates from grain, sweet, and forage sorghum) clustered together into one group, while the majority of isolates from $S$. halepense formed a second group. One Johnsongrass isolate (JG16.001) clustered with the S. bicolor isolates (Fig. 3 ). One sweet sorghum isolate (SS1.001) and one Johnsongrass isolate (JG14.001) were intermediate between the two groups (Fig. 3).
DAPC was performed to identify more robust groupings of genetically similar individuals. In all, 8 of 10 runs of the "find.cluster" function resulted in a most likely number of clusters $(k)$ of 7 . Confirming the association with host species, Johnsongrass isolates were grouped primarily into clusters 2,3 , and 7 whereas most isolates from S. bicolor were found in clusters 1, 4, 5, and 6 (Fig. 4; Supplementary Table S5). Exceptions included one isolate from sweet sorghum (SS1.001) in cluster 7 and two isolates from Johnsongrass (JG14.001 and JG16.001) in cluster 1. Most clusters included isolates with multiple origins, suggesting that gene flow had occurred among locations. All the forage sorghum isolates grouped together in cluster 5 and all but two of the grain sorghum isolates were in cluster 6 .

There was no evidence for random mating in the total population (105 isolates; $\mathrm{r}_{\mathrm{D}}=0.032, P$ value $<0.001$ ) or in the subpopulations on sweet sorghum (45 isolates; $\mathrm{r}_{\mathrm{D}}=0.040, P$ value $\left.<0.001\right)$ or Johnsongrass ( 38 isolates; $\mathrm{r}_{\mathrm{D}}=0.027, P$ value $<0.001$ ) (Supplementary Fig. S3). The other subpopulations were too small to analyze.

Pathogenicity assays. Thirty-one isolates from Johnsongrass and from sweet, grain, and forage sorghum, representing diverse geographic and host origins, were tested for pathogenicity on the sweet sorghum inbred Sugar Drip (Table 4). These isolates included members

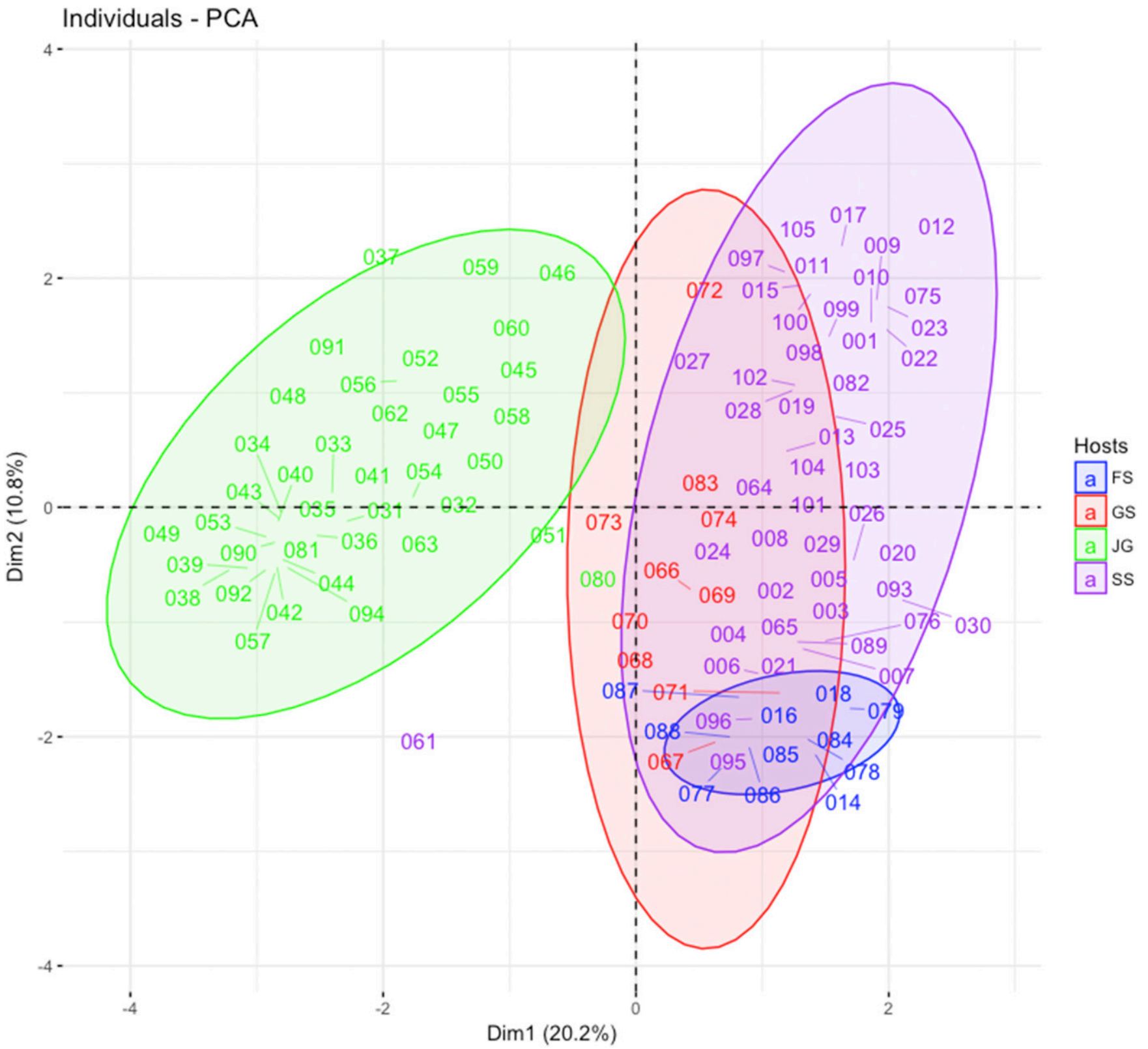

Fig. 3. Clusters of isolates of Colletotrichum sublineola based on random amplified polymorphic DNA fingerprint data subjected to principal components analysis (PCA). Isolates are colored-coded according to the host of origin: blue $=$ forage sorghum, red $=$ grain sorghum, green $=$ Johnsongrass, and purple $=$ sweet sorghum . 
of the most common combined haplotypes. All of the isolates were compared with the negative control, the nonpathogenic maize isolate M30.001. Six isolates from S. halepense and four from S. bicolor did not differ statistically from the negative control when inoculated on Sugar Drip (Table 4; Supplementary Table S6). The other isolates caused varying levels of disease (expressed as AUDPC) in the greenhouse (Table 4). Most of these pathogenic isolates were from S. bicolor; however, there were three Johnsongrass isolates, all from Kentucky, that were also pathogenic to Sugar Drip (Table 5). All of the pathogenic isolates produced typical foliar anthracnose symptoms, consisting of elongated individual or coalescent reddish lesions with necrotic centers (not shown). On average, the Johnsongrass isolates were less aggressive (had lower AUDPC values) than the isolates from $S$. bicolor but the ranges overlapped among the two groups (Table 5).

A subset of 19 isolates from the experiments on Sugar Drip, including all but 2 of the isolates that were nonpathogenic on that variety, was used to inoculate several additional lines of S. bicolor (Table 5). Results revealed that all of the isolates from S. bicolor (including those that were nonpathogenic to Sugar Drip) could cause disease on at least one of these sorghum lines (Table 5).
Some isolates (e.g., SS63.001) were pathogenic to most of the sorghum lines tested, whereas others (e.g., SS100.001) were pathogenic to only a few (Table 5). Among the Johnsongrass isolates, some appeared to be completely nonpathogenic to $S$. bicolor because they didn't cause disease on any of the lines, whereas others were pathogenic on only some of the lines (Table 5). Honey was susceptible to all of the isolates from $S$. bicolor that were tested, as well as to four isolates from $S$. halepense. At the other extreme, Keller was resistant to all of the fungal isolates that were tested on it. Evaluation of pathogenicity patterns suggested the presence of at least 12 races among the 15 isolates that were pathogenic on S. bicolor (Fig. 5).

\section{Discussion}

Sorghum originated in Africa, and C. sublineola is specific to Sorghum spp.; thus, it is most likely that the pathogen was introduced to the United States together with its host, perhaps on seed because it has been reported to be seed-transmitted across long distances (Cardwell et al. 1989; Zhang et al. 2017). In 1857, Leonard Wray imported 16 varieties of sweet sorghum from Africa, including Honey and Sourless (Swanson and Laude 1934). Most of the types of sweet sorghum currently grown in the United States for syrup were developed

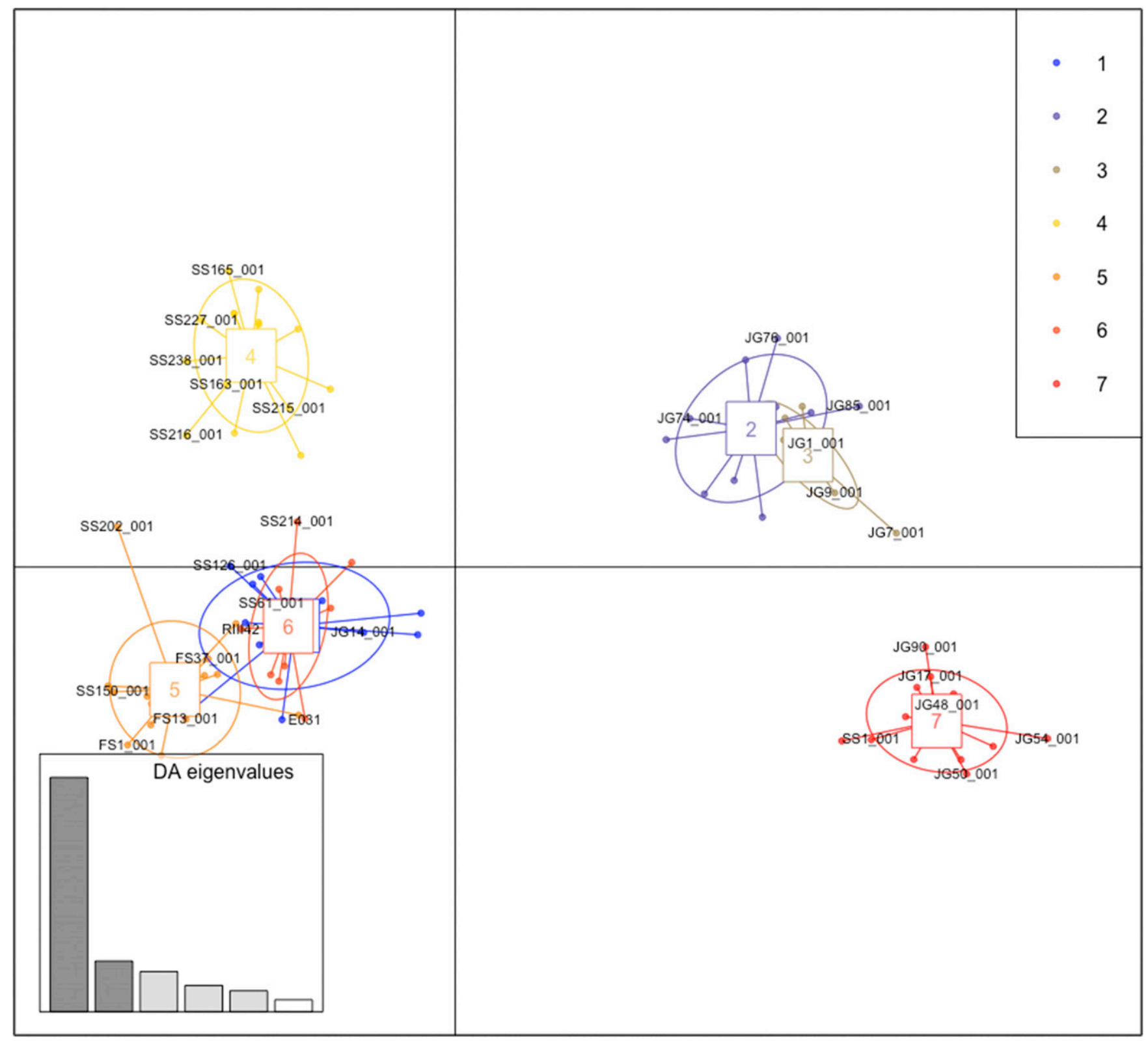

Fig. 4. Clusters of isolates of Colletotrichum sublineola based on random amplified polymorphic DNA fingerprint data subjected to discriminate analysis (DA) of principle components. 
from these 16 varieties. Grain sorghum was introduced about 20 years after sweet sorghum, and forage sorghum was introduced in 1909 (Swanson and Laude 1934). The sorghum relative S. halepense, which is native to the Mediterranean, was brought to the United States for use as forage before 1830 (Ball 1902) and, by 1900, it had spread throughout the Southeast as a noxious weed. It has hybridized with cultivated $S$. bicolor varieties, so that the current population comprises numerous ecotypes containing various quantities of the S. bicolor genome (Morrell et al. 2005; Paterson et al. 1995). Johnsongrass is commonly infected by C. sublineola (Paterson et al. 1995). As a genetically diverse, open-pollinated perennial (Hill and Forer 1981; McWhorter 1981), it is possible that Johnsongrass could serve as an effective refuge for the anthracnose pathogen and as an incubator for the evolution of new races that could affect sweet sorghum production.

We recently reported that two isolates of $C$. sublineola from Johnsongrass in Kentucky were capable of completing their lifecycle when they were inoculated at a relatively high population density on Sugar Drip sweet sorghum in the field (Xavier et al. 2017). However, these isolates were significantly less aggressive than isolates from S. bicolor; thus, it was unclear whether or not cross-infection occurs under natural field conditions. To our knowledge, only one previous study has addressed this question. Rosewich et al. (1998) reported that isolates from Johnsongrass belonged to a population that was distinct from the isolates from grain sorghum in nearby fields in Texas, suggesting that cross-infection of grain sorghum

Table 4. Pathogenicity of 34 strains of Colletotrichum sublineola in comparison with the negative control C. graminicola on Sugar Drip in greenhouse inoculations

\begin{tabular}{llr}
\hline Straina & AUDPC & \\
\hline CgS11 (2) & $3.7^{*}$ & $<0.0001$ \\
CsTx430BB (1) & 0.5 & 0.9980 \\
GS1.001 (1) & $3.2^{*}$ & $<0.0002$ \\
FS13.001 (1) & $4.0^{*}$ & $<0.0001$ \\
FS34.001 (1) & 1.3 & 0.2363 \\
FS37.00 (1) & $2.4^{*}$ & 0.0005 \\
FS41.001 (1) & $3.0^{*}$ & $<0.0001$ \\
FS5.001 (1) & $3.1^{*}$ & $<0.0001$ \\
FS8.001 (1) & $2.0^{*}$ & 0.0081 \\
JG102.001 (2) & 0.7 & 0.5951 \\
JG18.001 (1) & 0.7 & 0.9682 \\
JG2.001 (1) & 0.0 & 1.0000 \\
JG34.001 (1) & $2.1^{*}$ & 0.0062 \\
JG42.001 (1) & $2.6^{*}$ & 0.0002 \\
JG62.001 (1) & 1.2 & 0.3053 \\
JG7.001 (1) & $2.3^{*}$ & 0.0016 \\
JG75.001 (2) & 0.7 & 0.8607 \\
JG9.001 (1) & 0.6 & 0.9943 \\
SS1.001 (1) & $3.3^{*}$ & $<0.0001$ \\
SS100.001 (1) & 1.5 & 0.1063 \\
SS107.001 (1) & $2.5^{*}$ & 0.0002 \\
SS124.001 (1) & $3.5^{*}$ & $<0.0001$ \\
SS159.001 (1) & $3.7^{*}$ & $<0.0001$ \\
SS204.001 (2) & $2.4^{*}$ & 0.0004 \\
SS240.001 (2) & $2.3^{*}$ & 0.0005 \\
SS26.001 (1) & $2.7^{*}$ & $<0.0001$ \\
SS29.001 (1) & $3.2^{*}$ & $<0.0001$ \\
SS41.001 (1) & 1.3 & $<0.0090$ \\
SS45.001 (1) & $4.5^{*}$ & $<0.0001$ \\
SS63.001 (1) & $5.4^{*}$ & $<0.0001$ \\
SS63.001 (2) & $2.7^{*}$ & NA \\
SS78.001 (1) & $2.8^{*}$ & \\
M30.001 (1) & 0.0 & 0.0001 \\
M30.001 (2) & 0.0 & \\
\hline WN & & \\
\hline
\end{tabular}

${ }^{a}$ Number in parentheses refers to the experiment in which the strain was tested.

${ }^{\mathrm{b}}$ Area under the disease progress curve. Asterisks indicate values that are significantly greater than the negative control (M30.001) at $P<0.05$.

${ }^{\mathrm{c}} \mathrm{NA}=$ not applicable. did not occur in that region. We tested the hypothesis that isolates from Johnsongrass belonged to the same population as those from S. bicolor by using several fingerprinting markers to analyze diversity among a collection of isolates. We also investigated their potential to cause anthracnose symptoms on a variety of sweet sorghum genotypes in the greenhouse.

Results of both RFLP and RAPD fingerprinting agreed that the population of $C$. sublineola in Kentucky and the southeastern United States is divided into two subpopulations that are associated with host species, and that cross-infection appears to be infrequent. Results with both types of markers also agreed that the populations on $S . b i$ color and on $S$. halepense are highly diverse, with multiple haplotypes in most locations, and relatively few occurring in more than one location. The DAPC cluster analysis based on RAPD markers suggested that there was gene flow among locations. This may indicate a role for regional seed transmission of the pathogen. Although phytosanitary inspections of seed for $C$. sublineola are not currently the norm, they should be explored as a mechanism for disease management in the future. The highest level of genetic diversity was among the grain sorghum isolates, although this could be because they were collected from locations around the world, across three decades. The least diverse were the forage sorghum isolates; however, these came from only three locations in Alabama, and they were collected in a single year. Sampling regimens were more similar for Johnsongrass and sweet sorghum isolates, and the fingerprinting analysis indicated that the more genetically diverse Johnsongrass plant population is associated with more genetic diversity in the pathogen. One contributor to diversity could be recombination: $C$. sublineola can undergo sexual development in the laboratory, although it has not been observed to do so in the field (Vaillancourt and Hanau 1992). However, analysis of the RAPD markers did not support the existence of random mating as a factor in either subpopulation or in the population as a whole.

Results from greenhouse pathogenicity assays indicated that some but not all isolates from Johnsongrass were capable of causing disease on S. bicolor. Johnsongrass isolates were less aggressive (expressed as AUDPC) than the majority of isolates from cultivated sorghum, although the ranges overlapped. One group of Johnsongrass isolates did not differ from the negative controls on Sugar Drip or on 12 other diverse sorghum genotypes. In a prior study, it was reported that two members of this apparently nonpathogenic group of Johnsongrass isolates (JG9.001 and JG18.001) produced limited numbers of sporulating acervuli in the field when inoculated at high population densities on susceptible Sugar Drip plants, even though they were nonpathogenic in greenhouse assays (Xavier et al. 2017). The current study indicates that there are two groups of isolates from Johnsongrass: one with very low levels of aggressiveness on S. bicolor and another that is intermediate in aggressiveness when compared with most isolates from cultivated sorghum. The demonstrated potential for cross-infection by some Johnsongrass isolates in the greenhouse assays contrasts with the molecular fingerprinting evidence, suggesting that cross-infection from $S$. halepense to $S$. bicolor is not common in the field. It seems likely that this relates to the relatively low levels of aggressiveness and reduced fitness of the Johnsongrass isolates on S. bicolor.

One sweet sorghum isolate (SS1.001) clustered together with the Johnsongrass isolates in the DAPC analyses. This isolate came from a single lesion on an $S$. bicolor plant of the heritage inbred variety Sourless growing on the UK experimental farm in Fayette County, $\mathrm{KY}$. In the DAPC analysis, the isolate clustered with Johnsongrass isolates from Kentucky, including other isolates from Fayette County. The SS1.001 isolate was not clonal with any other isolate in the collection but it did have multiple telomere bands, similar to most of the Johnsongrass isolates. We propose that this isolate represents a cross-infection event from Johnsongrass. If so, the isolate is particularly well adapted to $S$. bicolor, with a level of aggressiveness similar to most other S. bicolor isolates and higher than any of the Johnsongrass isolates that were tested. This isolate also had the ability to infect six of the eight sorghum lines that were tested, whereas none of the Johnsongrass isolates was able to infect more than three 
of the lines. Two genetically similar Johnsongrass isolates from the same field in Kentucky, JG14.001 and JG16.001, grouped with $S$. bicolor isolates. These two isolates may represent crossinfection events in the other direction, from S. bicolor to Johnsongrass. Beyond these three examples, representing less than $1 \%$ of the isolates we sampled, there was no evidence for cross-infection among the populations.

None of the RFLP or RAPD marker haplotypes was found in isolates from both $S$. bicolor and $S$. halepense, with the sole exception of the telomere RFLP haplotype 33, which was identified in one Johnsongrass isolate (JG35.001). Haplotype 33 was characterized by a single hybridizing band. It was the most common and widespread haplotype among $C$. sublineola isolates in the southeastern United States. It was also present in an isolate from Africa, which might indicate that it is an old haplotype that established itself prior to divergence of the pathogen population on the different host species in our region. Its relative dominance on sweet and forage sorghum suggests the possibility of a fitness advantage on that host or of a founder population that has been spread along with cultivation of the crop.

An alternative hypothesis is that haplotype 33 has resulted from the horizontal transfer of DNA among unrelated isolates. The single telomere fragment in haplotype 33 could be due to integration at all of the chromosome ends of a telomere-targeted transposable element that contains a restriction site for the enzyme used for the Southern blot. In perennial ryegrass isolates of Magnaporthe oryzae, retrotransposons targeted specifically to the telomeres, called "MoTeR" elements, resulted in alterations in the RFLP patterns with the telomere probe (Starnes et al. 2012). Integration and propagation of a transposon could occur in isolates that are not closely related by

Table 5. Pathogenicity of 20 isolates of Colletotrichum on 12 genetically diverse inbred lines of Sorghum bicolor in greenhouse inoculations ${ }^{\mathrm{a}}$

\begin{tabular}{|c|c|c|c|c|c|c|c|c|c|c|c|c|}
\hline Strain $^{\mathbf{b}}$ & Bailey & Chinese Amber & Cowper & Dale & Yellow Milo & Honey & N100 & Orange & Planter & Simon & Della & Keller \\
\hline CgSl1 (1) & 0.0 & 0.0 & $1.3^{*}$ & 0.0 & 0.0 & $4.0^{*}$ & $0.7^{*}$ & $3.3^{*}$ & $4.0^{*}$ & $4.0^{*}$ & 0.0 & 0.0 \\
\hline CsTX430BB (2) & $1.0^{*}$ & 0.7 & 0.0 & 0.2 & 0.4 & $1.6^{*}$ & 0.0 & 0.0 & 0.0 & 0.0 & NT & NT \\
\hline GS1.001 (1) & 0.0 & 0.0 & 0.0 & $1.7^{*}$ & $4.0^{*}$ & $3.3^{*}$ & 0.3 & 0.3 & 0.0 & $1.3^{*}$ & $0.8^{*}$ & 0.0 \\
\hline FS34.001 (2) & 0.0 & 0.0 & 0.0 & 0.0 & $1.7^{*}$ & $2.5^{*}$ & 0.0 & 0.0 & $0.8^{*}$ & 0.3 & NT & NT \\
\hline JG102.001 (1) & 0.0 & 0.0 & 0.0 & 0.0 & 0.0 & 0.0 & 0.0 & 0.0 & 0.0 & 0.0 & 0.0 & 0.0 \\
\hline JG18.001 (1) & 0.0 & 0.0 & 0.0 & 0.0 & 0.0 & 0.0 & 0.0 & 0.0 & 0.0 & 0.0 & 0.0 & 0.0 \\
\hline JG34.001 (2) & 0.0 & 0.6 & 0.2 & 0.0 & 0.0 & $3.3^{*}$ & 0.0 & 0.0 & $1.2^{*}$ & 0.3 & NT & NT \\
\hline JG42.001 (2) & 0.0 & $1.2 *$ & 0.0 & 0.0 & 0.2 & $1.7^{*}$ & 0.0 & 0.0 & 0.2 & 0.5 & NT & NT \\
\hline JG7.001 (2) & 0.0 & $1.5^{*}$ & 0.0 & 0.0 & 0.0 & $1.0^{*}$ & 0.0 & 0.0 & 0.3 & 0.2 & NT & NT \\
\hline JG75.001 (1) & 0.0 & 0.0 & 0.0 & 0.0 & 0.0 & 0.0 & 0.0 & 0.0 & 0.0 & 0.0 & 0.0 & 0.0 \\
\hline JG9.001 (1) & 0.0 & 0.0 & 0.0 & 0.0 & 0.0 & 0.0 & 0.0 & 0.0 & 0.0 & 0.0 & 0.0 & 0.0 \\
\hline JG90.001 (2) & 0.8 & 0.5 & 0.0 & 0.0 & 0.0 & $2.5^{*}$ & 0.0 & 0.5 & $1.3^{*}$ & 0.3 & NT & NT \\
\hline SS1.001 (1) & $2.8^{*}$ & $3.3^{*}$ & 0.0 & 0.0 & 0.0 & $3.7^{*}$ & 0.0 & 0.3 & $3.5^{*}$ & $1.0^{*}$ & 0.0 & 0.0 \\
\hline SS100.001 (2) & $2.5^{*}$ & 0.3 & 0.0 & 0.2 & 0.0 & $2.6^{*}$ & 0.0 & 0.2 & 0.3 & 0.0 & NT & NT \\
\hline SS204.001 (1) & $3.5^{*}$ & $2.0^{*}$ & 0.0 & $0.8^{*}$ & 0.0 & $3.7^{*}$ & 0.0 & 0.0 & 0.0 & $1.0^{*}$ & 0.0 & 0.0 \\
\hline SS240.001 (1) & 0.0 & 0.0 & 0.0 & 0.0 & $2.3^{*}$ & $4.0^{*}$ & 0.0 & 0.0 & 0.0 & 0.3 & 0.0 & 0.0 \\
\hline SS41.001 (2) & $2.1^{*}$ & 0.0 & 0.0 & 0.3 & $2.4^{*}$ & $2.8^{*}$ & 0.0 & 0.0 & 0.8 & 0.2 & NT & NT \\
\hline SS63.001 (1) & $3.3^{*}$ & 0.0 & $3.5^{*}$ & 0.0 & $3.5^{*}$ & $3.8^{*}$ & 0.3 & $2.2 *$ & $4.0^{*}$ & $4.0^{*}$ & 0.0 & 0.0 \\
\hline SS63.001 (2) & $3.5^{*}$ & 0.0 & $2.8^{*}$ & 0.0 & $2.2^{*}$ & $3.8^{*}$ & 0.3 & $2.8^{*}$ & $3.2 *$ & $3.3^{*}$ & NT & NT \\
\hline SS90.001 (1) & $3.7 *$ & $2.0^{*}$ & 0.0 & $1.7^{*}$ & 0.0 & $3.0^{*}$ & 0.0 & 0.0 & 0.0 & 0.5 & 0.0 & 0.0 \\
\hline M30.001 (1) & 0.0 & 0.0 & 0.0 & 0.0 & 0.0 & 0.0 & 0.0 & 0.0 & 0.0 & 0.0 & 0.0 & 0.0 \\
\hline M30.001 (2) & 0.0 & 0.0 & 0.0 & 0.0 & 0.0 & 0.0 & 0.0 & 0.0 & 0.0 & 0.0 & NT & NT \\
\hline
\end{tabular}

${ }^{a}$ Values represent the average disease incidence at 3 weeks after inoculation. Asterisks indicate values that are significantly greater than the negative control

(M30.001) at $P<0.05$. NT $=$ not tested.

${ }^{\mathrm{b}}$ Number in parentheses refers to the experiment in which the strain was tested.

\begin{tabular}{|c|c|c|c|c|c|c|c|c|c|c|c|}
\hline \multirow[b]{2}{*}{ Race } & \multirow[b]{2}{*}{ Strain } & \multirow[b]{2}{*}{$\begin{array}{l}\text { Combined } \\
\text { Haplotype }\end{array}$} & \multirow[b]{2}{*}{ Source } & \multicolumn{8}{|c|}{ Pathogenic On: } \\
\hline & & & & Honey & Sugar Drip & Bailey & $\begin{array}{c}\text { Chinese } \\
\text { Amber }\end{array}$ & Planter & Simon & $\begin{array}{c}\text { Dwarf } \\
\text { Yellow Milo }\end{array}$ & Dale \\
\hline 1 & SS63.001 & $4: 33$ & Sweet Sorghum & & & & & & & & \\
\hline 2 & CgSl1 & $98: 107$ & Grain Sorghum & & & & & & & & \\
\hline 3 & GS1.001 & $99: 33$ & Grain Sorghum & & & & & & & & \\
\hline 4 & SS1.001 & 5:34 & Sweet Sorghum & & & & & & & & \\
\hline 5 & SS204.001 & $17: 33$ & Sweet Sorghum & & & & & & & & \\
\hline 6 & SS90.001 & $17: 33$ & Sweet Sorghum & & & & & & & & \\
\hline 7 & FS34.001 & 19:33 & Forage Sorghum & & & & & & & & \\
\hline 8 & SS240.001 & $19: 33$ & Sweet Sorghum & & & & & & & & \\
\hline 9 & JG34.001 & $42: 60$ & Johnsongrass & & & & & & & & \\
\hline 9 & JG90.001 & $49: 83$ & Johnsongrass & & & & & & & & \\
\hline 10 & JG42.001 & $42: 60$ & Johnsongrass & & & & & & & & \\
\hline 10 & JG7.001 & $39: 56$ & Johnsongrass & & & & & & & & \\
\hline 11 & SS41.001 & 1:33 & Sweet Sorghum & & & & & & & & \\
\hline 12 & CsTX430BB & $17: 33$ & Grain Sorghum & & & & & & & & \\
\hline 12 & SS100.001 & $17: 33$ & Sweet Sorghum & & & & & & & & \\
\hline $\mathrm{NP}$ & $J G 9.001$ & $38: 57$ & Johnsongrass & & & & & & & & \\
\hline $\mathrm{NP}$ & JG75.001 & $47: 78$ & Johnsongrass & & & & & & & & \\
\hline $\mathrm{NP}$ & JG102.001 & $50: 84$ & Johnsongrass & & & & & & & & \\
\hline $\mathrm{NP}$ & JG18.001 & $43: 61$ & Johnsongrass & & & & & & & & \\
\hline NP & M30.001 & 101:113 & Maize & & & & & & & & \\
\hline
\end{tabular}

Fig. 5. Race identities of 20 genetically and geographically diverse strains of Colletotrichum, as defined by greenhouse inoculations on eight differential cultivars of Sorghum bicolor Dark gray boxes $=$ virulent. White boxes $=$ avirulent. NP $=$ nonpathogenic strains (avirulent on all of the differential cultivars in greenhouse assays). 
ancestry, a possibility that is supported by the large number of transposase haplotypes that were found in association with the telomere haplotype 33 . We know that the telomere-targeted transposon is not CgTn1, because isolate JG35.001 does not hybridize strongly to the $\mathrm{CgTn} 1$ probe. If horizontal transfer of a telomere-targeted transposon explains the 33 haplotype, it is apparent that the movement from the $S$. bicolor population into the $S$. halepense population is not common, and this may imply that there are barriers to anastomosis between the members of the two groups.

The results of the current study imply that, although crossinfections are infrequent, Johnsongrass could nonetheless serve as a reservoir for $C$. sublineola during crop rotation schemes, and could also be a source of novel races. The example of SS1.001 indicates that such events can give rise to aggressive new races of the pathogen. This would complicate the implementation of an effective disease management program and efforts to develop new varieties of sweet sorghum with durable resistance.

\section{Acknowledgments}

We thank E. Nuckles, D. Brown, S. Holton, A. Gennett, and J. Judy for excellent technical assistance; A. Saballos, W. Vermerris, C. LaPaire, B. Anderson, J. Knoll, A. Hagan, R. Thompson, and D. Townsend for supplying samples of diseased tissue for pathogen isolation; T. Pfeiffer and G. Pederson for supplying sorghum seed; C. Wood, E. Roualdes, S. W. Janse, and E. Roemmele of the University of Kentucky Department of Statistics for their statistical expertise; and M. Farman for helpful discussions and suggestions.

\section{Literature Cited}

Agapow, P.-M., and Burt, A. 2001. Indices of multilocus linkage disequilibrium. Mol. Ecol. Notes 1:101-102.

Ali, M. E. K., and Warren, H. L. 1987. Physiological races of Colletotrichum graminicola on Sorghum. Plant Dis. 71:402-404.

Ball, C. R. 1902. Johnson Grass: Report of investigations made during the season of 1901 (No.11). U.S. Government Printing Office, Washington, DC.

Baroncelli, R., Sanz-Martin, J. M., Rech, G. E., Sukno, S. A., and Thon, M. R. 2014. Draft genome sequence of Colletotrichum sublineola, a destructive pathogen of cultivated sorghum. Genome Announc. 2:e00540-e14.

Bitzer, M. J. 1997. Production of Sweet Sorghum for Syrup in Kentucky. AGR122. Cooperative Extension Service, College of Agriculture, University of Kentucky, Lexington.

Bitzer, M. J. 2009. Sweet Sorghum for Syrup. AGR-123. Cooperative Extension Service, College of Agriculture, University of Kentucky, Lexington.

Boora, K. S., Frederiksen, R., and Magill, C. 1998. DNA-based markers for a recessive gene conferring anthracnose resistance in sorghum. Crop Sci. 38: 1708-1709.

Browning, M., Rowley, L. V., Zeng, P., Chandlee, J. M., and Jackson, N. 1999. Morphological, pathogenic, and genetic comparisons of Colletotrichum graminicola isolates from Poaceae. Plant Dis. 83:286-292.

Buiate, E., Xavier, K., Moore, N., Torres, M., Farman, M., Schardl, C., and Vaillancourt, L. 2017. A comparative genomic analysis of putative pathogenicity genes in the host-specific sibling species Colletotrichum graminicola and Colletotrichum sublineola. BMC Genomics 18:67.

Campbell, C. L., and Madden, L. V. 1990. Introduction to Plant Disease Epidemiology. John Wiley \& Sons, New York.

Cardwell, K. F., Hepperly, P. R., and Frederiksen, R. A. 1989. Pathotypes of Colletotrichum graminicola and seed transmission of sorghum anthracnose. Plant Dis. 73:255-257.

Casela, C., and Frederiksen, R. 1993. Variability in the sorghum anthracnose fungus Colletotrichum graminicola in Brazil and USA. Page 310 in: Durability of Disease Resistance. T. Jacobs and J. E. Parlevliet, eds. Springer Science+ Business Media, Dordrecht, The Netherlands.

Casela, C. R., Ferreira, A. S., and Santos, F. G. 1998. Associação de virulência de Colletotrichum graminicola à resistência genética em sorgo. Fitopatol. Bras. 23:143-146.

Casela, C. R., Ferreira, A. S., Zeller, K. A., and Levy, M. 1995. Pathotype variation in the sorghum anthracnose fungus: A phylogenetic perspective for resistance breeding. Pages 257-276 in: Disease Analysis through Genetics and Molecular Biology: Interdisciplinary Bridges to Improved Sorghum and Millet Crops. J. F. Leslie and R. A. Frederiksen, eds. Iowa State University Press, Ames.

Casela, C. R., Santos, F., and Ferreira, A. S. 2000. Associacoes de patogenicidade e diversidade fenotipica de Colletotrichum graminicola, agente causal da antracnose em sorgo. Fitopatol. Bras. 25:517-521.

Chala, A., Alemu, T., Prom, L., and Tronsmo, A. 2010a. Effect of host genotypes and weather variables on the severity and temporal dynamics of sorghum anthracnose in Ethiopia. Plant Pathol. J. (Faisalabad) 9:39-46.

Chala, A., Brurberg, M., and Tronsmo, A. 2010b. Incidence and severity of sorghum anthracnose in Ethiopia. Plant Pathol. J. (Faisalabad) 9:23-30.
Chala, A., Tronsmo, A., and Brurberg, M. 2011. Genetic differentiation and gene flow in Colletotrichum sublineolum in Ethiopia, the centre of origin and diversity of sorghum, as revealed by AFLP analysis. Plant Pathol. 60:474-482.

Coleman, O. H., and Stokes, I. 1954. The inheritance of resistance to stalk red rot in sorghum. Agron. J. 46:61-63.

Cutz, L., Sanchez-Delgado, S., Ruiz-Rivas, U., and Santana, D. 2013. Bioenergy production in Central America: Integration of sweet sorghum into sugar mills. Renew. Sustain. Energy Rev. 25:529-542.

Ferreira, A. S., and Warren, H. L. 1982. Resistance of sorghum to Colletotrichum sublineolum. Plant Dis. 66:773-775.

Frederiksen, R. A., and Odvody, G. N. 2000. Compendium of Sorghum Diseases. American Phytopathological Society, St. Paul, MN.

Guthrie, P. A. I., Magill, C. W., Frederiksen, R. A., and Odvody, G. N. 1992. Random amplified polymorphic DNA markers: A system for identifying and differentiating isolates of Colletotrichum graminicola. Phytopathology 82: 832-835.

Hagan, A., Bowen, K., Pegues, M., and Jones, J. 2014. Nitrogen rate and variety impact diseases and yield of sorghum for biofuel. Agron. J. 106:1205-1211.

Harris, H. B., Johnson, B. J., Dobson, J. W., and Luttrell, E. S. 1964. Evaluation of anthracnose on grain sorghum. Crop Sci. 4:460-462.

Hill, R. J. G. S., and Forer, L. B. 1981. Mile-a-minute, Polygonum perfoliatum L. (Polygonaceae), a new potential orchard and nursery weed. Regul. Hortic. 7: 25-28.

Hunter, E., and Anderson, I. 1997. Sweet sorghum. Hortic. Rev. (Am. Soc. Hortic Sci.) 21:73-104.

IJdo, J. W., Wells, R. A., Baldini, A., and Reeders, S. T. 1991. Improved telomere detection using a telomere repeat probe $(\text { TTAGGG) })_{n}$ generated by PCR. Nucleic Acids Res. 19:4780.

Jamil, F., and Nicholson, R. 1987. Susceptibility of corn to isolates of Colletotrichum graminicola pathogenic to other grasses. Plant Dis. 71:809-810.

Jombart, T. 2008. Adegenet: A R package for the multivariate analysis of genetic markers. Bioinformatics 24:1403-1405.

Kim, M., and Day, D. F. 2011. Composition of sugar cane, energy cane, and sweet sorghum suitable for ethanol production at Louisiana sugar mills. J. Ind. Microbiol. Biotechnol. 38:803-807.

Koçar, G., and Civaş, N. 2013. An overview of biofuels from energy crops: Current status and future prospects. Renew. Sustain. Energy Rev. 28:900-916.

LeBeau, F. J., and Coleman, O. H. 1950. The inheritance of resistance in sorghum to leaf anthracnose. Agon. J. 42:33-34.

LeBeau, F. J., Stokes, I., and Coleman, O. H. 1951. Anthracnose and red rot of sorghum. U.S. Government Printing Office, Washington, DC.

McWhorter, C. G. 1981. Control of Johnsongrass ecotypes. Weed Sci. 19:229-233

Morrell, P., Williams-Coplin, T., Lattu, A., Bowers, J., Chandler, J., and Paterson, A. 2005. Crop-to-weed introgression has impacted allelic composition of johnsongrass populations with and without recent exposure to cultivated sorghum. Mol. Ecol. 14:2143-2154.

Muse, R. R., Vaillancourt, L. J., and Young, W. J. 2003. Cutter Assembly for Microscope and Related Method. Plant Pathology Faculty Patents, 2. Online publication. https://uknowledge.uky.edu/plantpath_patents/2/

Paterson, A. H., Schertz, K. F., Lin, Y. R., Liu, S. C., and Chang, Y. L. 1995. The weediness of wild plants: Molecular analysis of genes influencing dispersal and persistence of johnsongrass, Sorghum halepense (L.) Pers. Proc. Natl. Acad. Sci. USA 92:6127-6131.

Pederson, G. A. 2010. Status of the U.S. Sweet Sorghum Collection for Biofuel Research. In: Proc. Int. Symp. Forage, Turfgrass and Biofuel Germplasm Res., Yangling, Xi'an, Shaanxi, China. https://www.ars.usda.gov/research/ publications/publication/?seqNo115=256041

Prom, L., Perumal, R., Erattaimuthu, S., Little, C R., No, E. G., Erpelding, J. E. Rooney, W. L., Odvody, G. N., and Magill, C. W. 2012. Genetic diversity and pathotype determination of Colletotrichum sublineolum isolates causing anthracnose in sorghum. Eur. J. Plant Pathol. 133:671-685.

Prom, L. K., Perumal, R., Erpelding, J., Isakeit, T., Montes-Garcia, N., and Magill, C. 2009. A pictorial technique for mass screening of sorghum germplasm for anthracnose (Colletotrichum sublineolum) resistance. Open Agric. J. 3:20-25.

Rosewich, U., Pettway, R., McDonald, B., Duncan, R., and Frederiksen, R. 1998 Genetic structure and temporal dynamics of a Colletotrichum graminicola population in a sorghum disease nursery. Phytopathology 88:1087-1093.

Sarath, G., Mitchell, R. B., Sattler, S. E., Funnell, D., Pedersen, J. F., Graybosch, R. A., and Vogel, K. P. 2008. Opportunities and roadblocks in utilizing forages and small grains for liquid fuels. J. Ind. Microbiol. Biotechnol. 35:343-354.

Sipos, B., Réczey, J., Somorai, Z., Kádár, Z., Dienes, D., and Réczey, K. 2009. Sweet sorghum as feedstock for ethanol production: Enzymatic hydrolysis of steam-pretreated bagasse. Appl. Biochem. Biotechnol. 153:151-162.

Starnes, J. H., Thornbury, D. W., Novikova, O. S., Rehmeyer, C. J., and Farman M. L. 2012. Telomere-targeted retrotransposons in the rice blast fungus Magnaporthe oryzae: Agents of telomere instability. Genetics 191:389-406.

Swanson, A. F., and Laude, H. H. 1934. Varieties of sorghum in Kansas. Agric Exp. Stn. Bull. 266.

Tenkouano, A., Miller, F. R., Hart, G. E., Frederiksen, R. A., and Nicholson, R. L. 1993. Phytoalexin assay in juvenile sorghum: An aid to breeding for anthracnose resistance. Crop Sci. 33:243-248.

Tesso, T., Perumal, R., Little, C. R., Adeyanju, A., Radwan, G. L., Prom, L. K., and Magill, C. W. 2012. Sorghum pathology and biotechnology-a fungal disease 
perspective: Part II. Anthracnose, stalk rot, and downy mildew. Eur. J. Plant Sci. Biotechnol. 6:31-44.

Thon, M., Nuckles, E., and Vaillancourt, L. 2000. Restriction enzyme-mediated integration used to produce pathogenicity mutants of Colletotrichum graminicola. Mol. Plant-Microbe Interact. 13:1356-1365.

Torres, M. F., Cuadros, D. F., and Vaillancourt, L. J. 2014. Evidence for a diffusible factor that induces susceptibility in the Colletotrichum-maize disease interaction. Mol. Plant Pathol. 15:80-93.

Tuite, J. 1969. Plant Pathological Methods. Fungi and Bacteria. Burgess Publishing Co., Minneapolis, MN.

Vaillancourt, L. J., and Hanau, R. M. 1992. Genetic and morphological comparisons of Glomerella (Colletotrichum) isolates from maize and from sorghum. Exp. Mycol. 16:219-229.

Valèrio, H., Rèsende, M., Weikert-Oliveira, R., and Casela, C. 2005. Virulence and molecular diversity in Colletotrichum graminicola from Brazil. Mycopathologia 159:449-459.

Warren, H. L. 1986. Leaf anthracnose. Pages 10-11 in: Compendium of Sorghum Diseases. R. A. Frederiksen, ed. American Phytopathological Society, St. Paul, MN.
Wheals, A. E., Basso, L. C., Alves, D. M., and Amorim, H. V. 1999. Fuel ethanol after 25 years. Trends Biotechnol. 17:482-487.

Williams, J. G., Kubelik, A. R., Livak, K. J., Rafalski, J. A., and Tingey, S. V. 1990. DNA polymorphisms amplified by arbitrary primers are useful as genetic markers. Nucleic Acids Res. 18:6531-6535.

Winberry, J. T. 1980. The sorghum syrup industry: 1854-1975. Agric. Hist. 54: 343-352.

Xavier, K., Pfeiffer, T., Parreira, D. F., Chopra, S., and Vaillancourt, L. 2017 Aggressiveness of Colletotrichum sublineola strains from Sorghum bicolor and S. halepense to sweet sorghum variety Sugar Drip, and their impact on yield. Plant Dis. 101:1578-1587.

Yu, X., Li, X., Wu, Y., Mitchell, S., Roozeboom, K., Wang, D., Bernardo, R., Wang, M., Pederson, G., Tesfaye, T., and Yu, J. 2014. Genomic selection of biomass traits in a global collection of 976 sorghum accessions. In: Proc. Plant Anim. Genome Conf. XXII (No. 011), San Diego, CA. https://pag.confex.com/ pag/xxii/webprogram/Paper12249.html

Zhang, Y., Wu, J., Su, H., Yang, J., Li, B., and Wu, C. 2017. Quarantine identification of Colletotrichum sublineola on imported Sorghum bicolor seeds. Mycosystema 36:1083-1088. 